\title{
Comparison of varying pollen source on productivity of sour cherry (Prunus cerasus L.) cultivars
}

\author{
Davarynejad, G.H.1, Nyéki, J.2 , Szabó, T. ${ }^{3}$, Tornyai, J. ${ }^{2}$, Szabó, Z.², Soltész, M. \& Davarynejad, E. ${ }^{4}$ \\ ${ }^{1}$ Department of Horticulture, Ferdowsi University of Mashhad Iran \\ ${ }^{2}$ University of Debrecen, Institute for Research and Development, Hungary \\ ${ }^{3}$ Fruit Research and Extension Institute, Újfehértó \\ ${ }^{4}$ Institute of Biological Production Systems, Leibniz University of Hannover, Germany
}

\begin{abstract}
Summary: Fruit set of five sour cherry cultivars ('Újfehértói fürtös', 'Éva', 'Petri', 'Pándy 279' and 'Csengődi') of eight years-old trees grown in Újfehértó, located in the Eastern north part of Hungary have been studied over two years (2008 \& 2009). Following reciprocally cross-pollination, free-pollination, self-pollination (autogamy) artificial self-pollination (geitonogamy) were studied. The results show that both maternal and paternal parent cultivates had significant effects on the percentage fruit set. Significant differences have been found in fruit set among years and among pollination treatments. Fruit set of free-pollinated Pándy 276 cultivar was low and seasonally highly variable. The yield of this cultivar on self-pollinated flowers was nearly $0 \%$, and in this treatment the maximum yields did not reach $10 \%$ in any of the examined cultivars. There was no significant relationship in the fruit set of free-pollination and natural self-pollination treatments.
\end{abstract}

Key words: Self-pollination, (autogamy) artificial self-pollination (geitonogamy), free- pollination, cross-pollination

\section{Introduction}

Sour cherry (Prunus cerasus L.) is a major crop with increasing acreage in the world. Fruit set percentage vary among sour cherry cultivars and even affected by the pollen donor cultivars. This variation in fruit set can be attributed to numerous environmental and genetic factors. Fertility of sour cherry cultivars has been studied by several researchers. Middlebrook (1916) described 9 self fertile sour cherry cultivars. Kostina (1926) also mentioned that among 29 sour cherry cultivars, 9 of them were self fertile. Crane and Lawrence (1929) showed that among sour cherry and duke cherry cultivars there were entirely self sterile and also cultivars with high degrees of self fertility. Kozma et al. (2003) categorized sour cherry varieties to 3 groups according their fertility relations.

First information's on sour cherry self fertility was mentioned by Maliga (1942) and Husz (1943). In sour cherry maximum fruit set due to self fertility could reach to $50 \%$. Amount of fruit set has been reported $64 \%$ (Nyéki et al, 2008), and up to $50 \%$ by Misic et al (1977).

According to (Nyéki et al. 2008) self-incompatible and partially self-incompatible sour cherry cultivars must be planted with associated polliniser cultivars. Appropriate polliniser cultivars are to be chosen from groups of synchronous blooming period. If three blooming time groups are considered, the partners should belong to the same group, whereas from the five groups, they may be taken from the neighboring blooming time groups too. In sour cherry it is so pronounced that cross-pollination is necessary to ensure commercial fruit set when natural pollinators are not enough (Nyéki et al. 2008). According to Ansary and Davarynejad (2008) at least 25\% fruit set is necessary for commercial fruit load. Selecting of pollen source for free-pollination is usually based on pollen availability and cultivars characters. Cherry growers often use different cultivars as pollen sources on different parts of plantations for obtaining adequate amounts of pollen for free-pollination. Nyéki et al. (2008) studied the fruit set of sour cherry cultivars from 1983 to 2002 and stated that, the average of 19 years self-set in the case of 'Újfehértói fürtös' was $5.8 \%$, and from free-pollination $22.8 \%$, this phenomena in the case of kantorjanoshi was $4.9 \%$, and $19.4 \%$ respectively. According to Davarynejad et al., (2008) Kántorjánosi, 'Éva' and 'Csengődi' cultivars belong to group of partially self fertile, while 'Újfehértói fürtös', and 'Petri', belong to self fertile group, which the fruit set by self-pollination are between $1.1-10 \%$. Self-fertility and its relation to fruit set obtained by free-pollination was assessed in several Hungarian and foreign cultivars by Nyéki et al. (2008). All variants of 'Pándy meggy' proved to be selfincompatible, and mutually inter-incompatible. Nyéki et al. 2008 called the attention to the fact that the selfincompatible Pándy meggy cannot be fertilised by several self-fertile cultivars (Debreceni bőtermő, Kántorjánosi, 'Újfehértói fürtös'), i.e. they are inter-incompatible. 
Fertility of sour cherry cultivars is also dependent on several plant pathology or pest problems (Holb et al., 2005; Holb \& Schnabel, 2005).

According to Pejkic Cited by Nyéki et al. (2008), the variety 'Pándy meggy' is practically male sterile because its microsporogenesis is irregular. In the meiotic configurations univalent chromosomes appear, consequently, the pollen is partially or totally empty. 'Pándy meggy' is cytologically an autopolyploid and allegedly originated from a diploid cherry or some kind of sweet $\mathrm{x}$ sour cherry hybrid combination.

The objective of this work was to study the efficiency of pollination in different cultivars of sour cherry using treatments of natural self-pollination, free-pollination and cross-pollination for determining the suitable cultivars to be used as pollinators for maternal cultivars.

\section{Materials and methods}

Studies were conducted to determine the effect of reciprocal cross-pollination in compare to free and selfpollination on fruit set of five commercially important sour cherry cultivars in 2008 and 2009. The orchard was planted in 1999 with the tree spacing of $4 \times 3.5 \mathrm{~m}$. at the Research and Extension Center for Fruit Growing, Újfehértó, Hungary. The latitude is $38^{\circ} 10^{\prime}$, the longitude is $30^{\circ} 37^{\prime}$, and the altitude is $1,050 \mathrm{~m}$. The mean annual temperature is $9.5^{\circ} \mathrm{C}$, and the annual rainfall over last 50 years was $583 \mathrm{~mm}$.Trees was grafted on Prunus mahleb seedling. Soil preparation, fertilization and pest control were according to local recommendations and need. Tree training was done according to commercial practices, with the general goal of a spindleshaped canopy. Irrigation and fruit thinning were not used.

'Újfehértói fürtös', Éva, 'Petri', Pándy 279 and 'Csengödi' sour cherry (Prunus avium L) were used for studding of free-pollination, self-pollination and reciprocally were used as male and female parents for cross-pollination experiments. Pollination was investigated on $20-30 \mathrm{~cm}$ long branches of different orientation (N; E; S; and W.) covered still at bud stage with parchment paper bags. Ten isolated units comprising 100-400 flowers represented each cultivar. Paper bags were eliminated 3-4 days after the blooming period ended. The effect of artificial self-pollination or geitonogamy was checked on isolated branches prepared as in the case of autogamy, except that the fully open flowers were hand pollinated once with previously collected and stored (at $+4^{\circ} \mathrm{C}$ ) pollen of the same variety, subsequently, the bags were restored until the end of blooming period as in the case of autogamy. Free-pollinated flowers were observed, equally, on 5-10 branches 1.5-2 meter above ground level of four different orientations and comprising 100-500 flowers per cultivars. Fruit set was registered and compared in all treatments at 1-2 weeks before fruit ripening.

Hand pollination, using pollen from parental cultivars (cross-pollination) was compared with natural pollination. Each treatment was randomly applied to one tree of each replicate pair and an equivalent number of flowers per tree
(33-52 depending on cultivar). As few flowers set naturally a similar number of flowers on these trees were also pollinated with pollen from the same cultivar (self-pollination). For hand pollination, partially open flowers were collected in the late afternoon and stored overnight in a moist environment, at ambient temperature. Pollen was extracted the following morning and used to pollinate flowers with the petals just beginning to open.

The differences in final fruit set percentage between different pollination method and different pollinasors were analyzed with a completely randomized factorial design separately for each cultivar and Duncan's multiple range test was conducted at $\alpha=0,05$. The statistical analysis was done using MSTATC software and results were plotted using MS Excel.

\section{Result and discussion}

Final fruit set of examined cultivars can be seen on Figure $1-A$. Depending on the cultivar, less than $0.57 \%$ (in 'Pándy $279^{\circ}$ ) to $12.21 \%$ (in 'Petri') of flowers that was isolated from strange pollen (natural self-pollination) set fruit, compared with the fruit set percentage from 7.53 (in 'Pándy 279') to $27.40 \%$ (in 'Petri') of flowers which was free-pollinated. According to Nyéki et al (2003) Most of the sour cherry cultivars are unable to set as much fruit at natural selfpollination. Since a high yield requires a 20-30\% fruit set, the small $(0.57 \%)$ self-set of 'Pándy $279^{\prime}$ may be attributed to the phenomenon termed practically male sterility of 'Pándy 279 '. This phenomenon reflects both environmental and genetic influences of this cultivar. This results are agree with the opinion of Nyéki et al. (2008), they belive that the variety 'Pándy meggy' is practically male sterile because its microsporogenesis is irregular. In the meiotic configurations univalent chromosomes appear, consequently, the pollen is partially or totally empty. 'Pándy meggy' is cytologically an autopolyploid and allegedly originated from a diploid cherry or some kind of sweet $\mathrm{x}$ sour cherry hybrid combination. Nyéki et al. (2008) mentioned that the pollen of the sour cherry 'Pándy meggy' is variable, irregular and shrivelled at high rates. In the same variety, Nyéki et al. (2008) stated that in most pollen mother cells the microsporogenesis is irregular and the grains produce are aneupolids. Our data corroborate the statement of Rjabov \& Rjabova (1970), which means that self-fertile sour cherry varieties are yielding safely every year because they are less subject to diversities due to weather and to growing site.

Average percentage of fruit-set following free-pollination and hand cross-pollination was distinctly higher in all cultivars in 2009 as compared with 2008, and apparently reflected more favorable temperatures at flowering time. These results agree with the results of Brózik et al. (1980). They believe that, in years favorable for pollination both, self-fertile and self-incompatible varieties set fruit abundantly, 40-60\%, whereas in less favorable years the difference was great between self-fertile types, 15-30\%, and self-incompatible types, $1.5-7.5 \%$. 

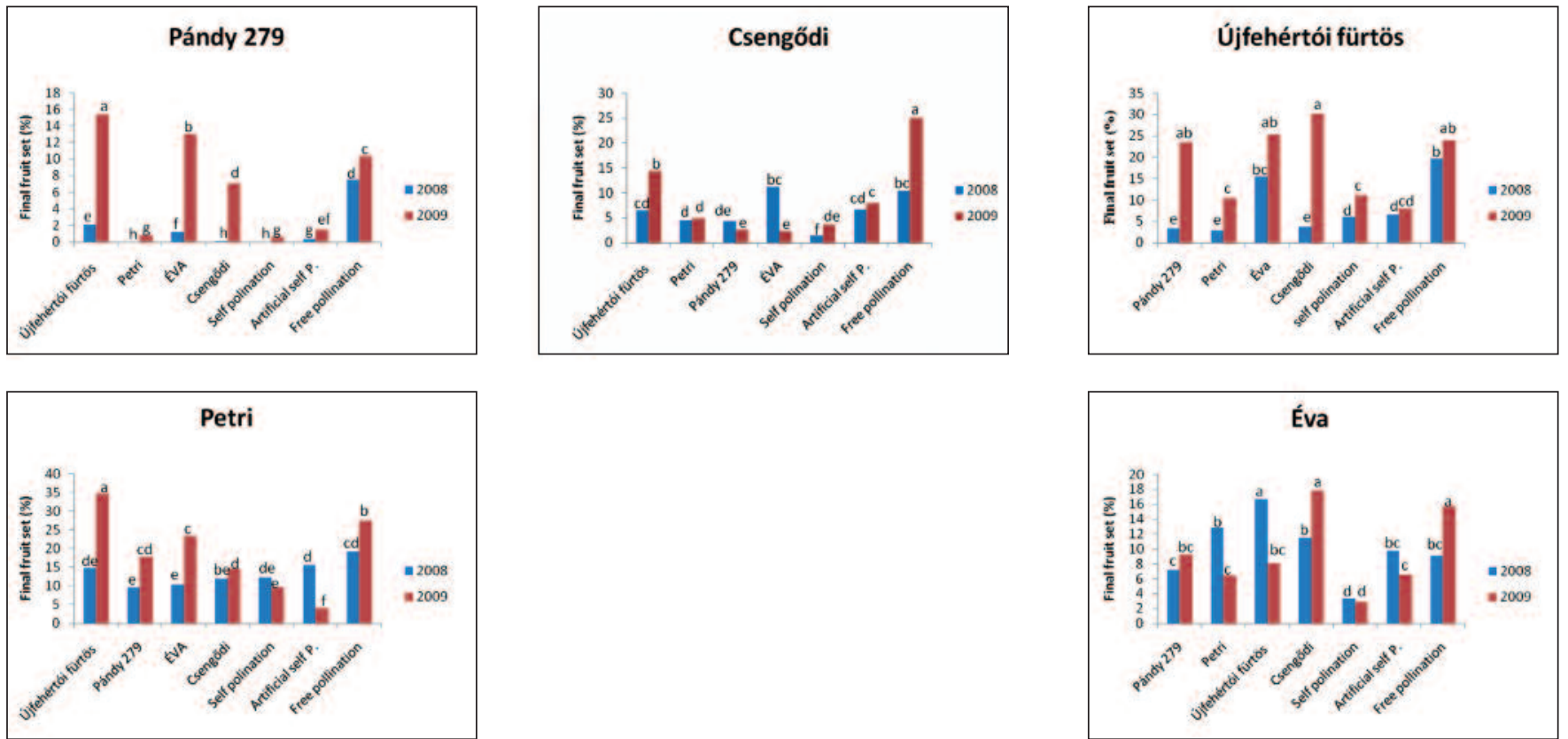

Fig 1: Comparison of fruit set percentage of sure cherry cultivars following natural self-pollination, free-pollination and cross-pollination. Columns followed by a different character indicate significant difference using Duncan's multiple range test $\alpha=0.05$.

Fruit-set of self-pollination of 'Újfehértói fürtös' was $5.99 \%$ in 2008 to $11.02 \%$ in 2009 while in the case of freepollination the fruit set was $19.66 \%$ and $24 \%$ respectively, 2.4 greater than self-pollination. The data confirm that in the case of hand-cross-pollination of 'Csengödi' as pollen donor for 'Újfehértói fürtös' as maternal plant the fruit set was $4.10 \%$ and $31.55 \%$ in 2008 and 2009 respectively. In 2008 and 2009, the percentage of hand-cross-pollination of 'Petri' on 'Újfehértói fürtös' was only $2.8 \%$ and $10.30 \%$, respectively while 'Éva', very closed to 'Pándy279' set ( $25.77 \%$ and $24.71 \%$ in 2009 . Totally it can be say that 'Éva', and 'Csengődi') were the best pollinizer for 'Újfehértói fürtös'.

The fruit set of 'Éva' cultivars following natural selfpollination, free-pollination and cross-pollination are shown on Figure 1-B. The percentage of free-pollination was greater in 2009 than it was in 2008. The fruit-set achieved by 'Pándy279' following cross-pollination in 2008 on 'Éva' was equivalent to that achieved in 2009 , but in the case of 'Petri' and 'Újfehértói fürtös' the fruit set was 2 time greater in 2008 in comparison to 2009.

Flowers cross-pollinated with "Csengődi", 'Újfehértói fürtös', 'Petri' and 'Pándy 279 ' pollen produced more fruit than did self-pollinated flowers. Flowers cross-pollinated with 'Pándy $279^{\text {' }}$ pollen did not produce as many fruit as "Csengődi", 'Újfehértói fürtös', and 'Petri' pollinated flowers. Cross-pollinating 'Eva' with 'Csengödi' resulted in the highest percentage fruit set and performed relatively well as pollen donors for 'Éva'.

Figure 1-C presents the results with respect to fruit set of different pollination treatments on 'Csengödi' as pollinated cultivar. Fruit set was high in the case of using 'Újfehértói fürtös' as pollen donor, but significantly low in the other crosses and two times lower than free-pollination treatment.
Also fruit set was significantly lower in the case of selfpollination in comparison to free and cross-pollination treatments. Although the fruit set from cross-pollination of pollen donor cultivars was not sufficient but the 'Újfehértói fürtös' was the best polliniser between the examined cultivars.

Figure 1-D shows that the cross-pollination of Petri cv. with the pollen grain of 'Újfehértói fürtös' $\mathrm{cv}$. gave the heaviest crop (31\%) on 2009 and $13 \%$ on 2008 , followed by 'Éva' cultivar by $23 \%$ on 2009 and $8 \%$ on 2008. Crosspollination with 'Pándy 279 ' and 'Csengődi' cultivars during the two studied seasons no set satisfied amount of fruit. Also 'Petri' cv. under cross-pollination with 'Csengődi' pollen grains yielded more fruits than with self-pollination.

The fruit set results of hand cross-pollinations in compare to self and free-pollination of Pándy cultivar are summarized in Fig.1-E. The highest fruit set was obtained from 'Újfehértói fürtös' pollen with 15\%; after that 'Éva' and Pándy combination gave 13\% fruit set in 2009. No fruit set was obtained from self-pollination which was very closed to fruit set resulted from cross-pollination with the pollen grain of 'Petri'.

\section{Conclusion}

Whereas most of sour cherry cultivars are partially selfincompatible or completely self-incompatible, crosspollination is necessary to ensure commercial fruit set and the orchard must be planted with associated polliniser cultivars. In sour cherry plantations selecting of pollen source for free-pollination appropriate polliniser cultivars is very important. Nyéki et al. (2008) called the attention to the fact that the self-incompatible Pándy meggy cannot be 
fertilised by several self-fertile cultivars (Debreceni bőtermő, Kántorjános, 'Újfehértói fürtös'), i.e. they are interincompatible. The result of this experiment shows that the Pándy and Petri are not suitable polliniser for examined sour cherry cultivars, but in the basis of several years experiments (Nyéki et al. 2008) the fruit set of Petri following selfpollination and free-pollination was higher than the other cultivars used in this experiment. Then the Petri could be an important cultivar for new plantations.

\section{References}

Ansary, M. \& G.H. Davarynejad (2008): Marked improvement of Hungarian sour cherries grown in Iran by cross-pollination 1: fruit set, Asian Journal of Plant Sciences, 7 (7): 687-691.

Brózik, S., Nyéki, J. \& M. Soltész, (1980): Sour cherry. (In: Nyéki, J. (eds.): Bloom biology and fertility of fruit cultivars). Mezőgazdasagi Kiadó, Budapest, 229-233.

Crane, M.B. \& Lawrence, W.J.C. (1929): Genetical and cytological aspects of incompatibility and sterility in cultivated fruits. Jour. Pom. Hort. Sci., 7: 276-301.

Davarynejad, G.H., Szabó, Z., Nyéki, J. \& Szabó T. (2008): Phenological stages, pollen production level, pollen viability and In vitro germination capability of some sour cherry cultivars. Asian Journal of Plant Sciences, 7 (7): 672-676.

Holb, I.J. \& Schnabel, G. (2005): Comparison of fungicide treatments combined with sanitation practices on brown rot blossom blight incidence, phytotoxicity, and yield for organic sour cherry production Plant disease, 89: 1164-1170.

Holb, I., Veisz, J. \& Abonyi, F. (2005): A meggy és cseresznye komplex ökológiai növényvédelmi technológiája. (In: Holb, I. (szerk.) A gyümölcsösök és a szőlő ökológiai növényvédelme) Mezőgazda Kiadó, Budapest, pp. 168-171.
Husz, B. (1943): Cited by: Nyéki. J and M. Soltész, (eds.): Floral biology of temperate zone fruit trees and small fruits. Akadémiai Kiadó, Budapest

Kostina, F. (1926): Cited by: Nyéki J. and M. Soltesz (eds.) 2003. Floral biology of temperate zone fruit trees and small fruits. Akadémiai Kiadó, Budapest

Kozma, P., Nyéki, J., Soltész, M. \& Szabó, Z. (ed.) (2003): Floral biology, pollination and fertilisation in temperate zone fruit species and grape. Akadémiai Kiadó, Budapest

Maliga, P. (1942): Adatok a 'Pándy meggy" virágbiológiájához. M. Kir. Kert. Akad. Közl., 8: 3-5.

Maliga, P. (1953): Cited by: Nyéki. J. and M. Soltesz (eds.): Floral biology of temperate zone fruit trees and small fruits. Akadémiai Kiadó, Budapest

Middlebrook, W.J. (1916): Pollination of fruit trees observations and experiments from 1904-1912. J. Board, Agricult., 22: 418-433.

Misic, P. O., Todorovic, P.R., Lekic, N.K. \& Pavlovic, C.V. (1977): Samooplodnj u visnje. Nauka u praksi., 7: 141-144.

Nyéki, J. Soltész, M. \& Szabó, Z. (2008): Morphology, biology and fertility of flowers in temperate zone fruits. Akadémiai Kiadó, Budapest, pp 450

Nyéki, J., Szabó, T. \& Szabó, Z. (2002): Blooming phenology and fertility of sour cherry cultivars selected in Hungary. International Journal of Horticultural Science, 8 (2): 33-37.

Nyéki, J., Szabó, T. \& Szabó, Z. (2003): Flowering, phenology and fertility of sour cherry (Prunus cerasus L.) cultivars selected in Hungary. Journal of Agricultural Science, 51 (47): 1

Nyéki, J., Szabó, Z. \& Salgim, S. S. (1992): Self and cross compatibility of Hungarian sour cherry cultivars. Acta Agr. Hung., 41 (1-2): 11-14.

Rjabov, I. N. \& Rjabova, A. N. (1970): Samoopylenie i perekrestnoe opylenie u cheresni, visni i vihsne-cheresni. Trudii Gosud. Nikit. Botan. Sada 4: 53-153. 